\title{
Characteristics of Lipid Peroxidation Processes and Antioxidant Status in Teenagers-Boys of Different Ethnic Groups with Exogenous Constitutional Obesity and Non-Alcoholic Fatty Liver Disease
}

\author{
Marina A. Darenskaya, PhD, $\mathrm{ScD}^{1 *}$; Oksana A. Gavrilova ${ }^{1}$; Lyubov V. Rychkova, $\mathrm{PhD}, \mathrm{ScD}^{1}$; \\ Larisa A. Zhdanova, $\mathrm{PhD}^{2}$; Ekaterina A. Buldaeva ${ }^{2}$; Lyudmila A. Grebenkina, $\mathrm{PhD}, \mathrm{ScD}^{1}$; \\ Elena V. Osipova, $\mathrm{PhD}^{1,3}$; Sergey I. Kolesnikov, Academician of the $\mathrm{RAS}^{1,4}$; \\ Lyubov I. Kolesnikova, Academician of the RAS ${ }^{1,3}$
}

'Scientific Centre for Family Health and Human Reproduction Problems, Irkutsk, Russia ${ }^{2}$ Children's Republican Clinical Hospital of the Ministry of Health of the Republic of Buryatia, Ulan-Ude, Russia 3Irkutsk State University, Irkutsk, Russia ${ }^{4}$ M.V. Lomonosov Moscow State University, Moscow, Russia

\begin{abstract}
The aim of this research was to study changes in the LPO-AOD processes in Mongoloid and Caucasian teenagers with exogenous constitutional obesity (ECO), including those complicated by non-alcoholic fatty liver disease (NAFLD).

Materials and Methods: A total of 18 Mongoloid teenage boys and 17 Caucasian teenage boys with NAFLD (Clinical group 1 and Clinical group 2, respectively) on the background of ECO of the first degree were examined. For comparison, data of 37 apparently healthy Mongoloid teenage boys (Control group 1) and 23 Caucasian teenage boys (Control group 2) was used. The plasma level of antioxidant parameters (total antioxidant activity [TTA], SOD activity, $\alpha$-tocopherol and retinol) and primary/ secondary products of LPO (conjugated dienes [CD], ketodienes and conjugated trienes [KD-CT], and thiobarbituric acid reactive substances [TBARS]) were determined using spectrophotometric and fluorometric methods.

Results: Evaluation of the activity of LPO reactions in Clinical group 1 indicated an increase in the content of compounds with DB relative to Control group 1. A similar trend was found in the concentration of CD and KD-CT. In Clinical group 2, we found a statistically significant increase only in the values of KD-CT. In the parameters of the AOD system, multidirectional changes of patients parameters compared with the control group were observed in Clinical group 1: the increased values of TAA, SOD activity, and reduced levels of $\alpha$-tocopherol, retinol, and GSSG. In Clinical group 2, lower values of $\alpha$-tocopherol, GSSG, and SOD activity were observed relative to Control group 2. Differences between the two ethnic groups were present in the control groups - the reduced level of TAA, GSH and the increased level of GSSG in the group of Mongoloids; just as in clinical groups with NAFLD, a high level of SOD activity was observed in Mongoloids compared to Caucasians.

Conclusion: The changes revealed in the redox state in Mongoloid and Caucasian teenagers with ECO and NAFLD indicate high activity of LPO processes and severe deficiency of antioxidant vitamins in patients of both ethnic groups. The obtained results allow us to recommend administration of antioxidant drugs in addition to courses of metabolic therapy in comprehensive treatment of patients with ECO and NAFLD. (International Journal of Biomedicine. 2018;8(4):306-310.)
\end{abstract}

Key Words: lipid peroxidation $\bullet$ antioxidant defense $\bullet$ teenage boys $\bullet$ obesity $\bullet$ non-alcoholic fatty liver disease

\section{Abbreviations}

AOD, antioxidative defense; BW, body weight; BMI, body mass index; CD, conjugated dienes; DB, unsaturated double bonds; GSH, reduced glutathione; GSSG, oxidized glutathione; ECO, exogenous constitutional obesity; KD-CT, ketodienes and conjugated trienes; LPO, lipid peroxidation; NAFLD, non-alcoholic fatty liver disease; SOD, superoxide dismutase; TAA, total antioxidant activity; TBARS, thiobarbituric acid reactive substances. 


\section{Introduction}

Non-alcoholic fatty liver disease (NAFLD) is considered to be a hepatic manifestation of metabolic syndrome, and therefore its prevalence is directly associated with the growth in obesity among the population. ${ }^{(1,2)}$ NAFLD (liver steatosis, fatty infiltration, and fatty liver) is a condition in which more than 5\% of the liver mass consists of fat, mostly triglycerides. If in addition to excessive accumulation of fat, an active inflammatory process takes place, it indicates the progression of the disease - nonalcoholic steatohepatitis, which significantly increases the risk of developing more serious liver diseases. ${ }^{(3,4)}$ Insulin resistance and hypertriglyceridemia are observed in patients with NAFLD; therefore, various methods of correcting overweight are often used, including lipotropic drugs and antioxidants. ${ }^{(5-8)}$ The results of numerous clinical studies indicate an increase in the incidence of exogenous constitutional obesity in teenagers, especially among boys; hence, studying NAFLD, being a frequent concomitant disease in obesity, is highly relevant. ${ }^{(9-12)}$ Currently, for this category of patients it seems appropriate to study changes in the LPO-AOD system, as well as to administer a range of antioxidants, individually selected according to the nature of the imbalance detected. ${ }^{(13-16)}$ It is also necessary to consider a patient's ethnicity when making a diagnosis and conducting differentiated health-improving programs and therapy measures. ${ }^{(17,18)}$

The aim of this research was to study changes in the LPO-AOD processes in Mongoloid and Caucasian teenagers with ECO, including those complicated by NAFLD.

\section{Materials and Methods}

A total of 18 Mongoloid teenage boys (mean age of $13.81 \pm 2.23$ years) and 17 Caucasian teenage boys (mean age of $14.87 \pm 1.59$ years) with NAFLD (Clinical group 1 and Clinical group 2, respectively) on the background of ECO of the first degree were examined. For comparison, data of 37 apparently healthy Mongoloid teenage boys (mean age$15.14 \pm 0.88$ years) (Control group 1 ) and 23 Caucasian teenage boys (mean age of $14.33 \pm 1.86$ years) (Control group 2) was used. All patients underwent inpatient treatment in Children's Republican Clinical Hospital of the Ministry of Health of the Republic of Buryatia (Ulan-Ude).

Inclusion criteria for clinical groups: age range of 13 to 17 years, excess body weight of more than 95 percentile for a given height, age and sex; absence of acute, or exacerbation of chronic diseases at the time of inclusion in the study and at least one month before it.

Exclusion criteria: symptomatic and genetic forms of obesity; intake of medications that could affect body weight and estimated metabolic parameters. The criteria for the diagnosis of NAFLD: ECO, diffuse changes of liver according to ultrasound and computed tomography of the abdominal cavity, absence of cytolysis (normal levels of ALT and AST), and exclusion of infectious etiology of hepatitis.

Blood samples were collected in accordance with the existing requirements in the morning on an empty stomach from the cubital vein. All teenagers were subjected to general clinical examination, including anamnestic data collection, physical examination, anthropometric data analysis (BW, height, BMI), blood pressure measurement, nutritional status assessment and determination of concentration of total cholesterol and triglycerides in blood serum, glucose tolerance testing.

The study was conducted in accordance with ethical principles of the WMA Declaration of Helsinki (1964, ed. 2013) and approved by the Ethics Committee of Scientific Centre for Family Health and Human Reproduction Problems. Written informed consent was obtained from the patient/ parent/guardian/ relative of each patient.

The intensity ofLPO processes was assessed by the content of DBs, primary/secondary products of LPO by the method of I.A. Volchegorskiî, ${ }^{(19)}$ based on the intensive absorption of conjugated diene structures by lipid hydroperoxides in the range $220 \mathrm{~nm}, 232 \mathrm{~nm}$, and $278 \mathrm{~nm}$. The content of TBARS was determined in the reaction with thiobarbituric acid using the fluorimetric method of V.B. Gavrilov et al. ${ }^{(20)}$ Total antioxidant activity (TAA) was evaluated by the method of G.I. Klebanov et al. ${ }^{(21)}$

To evaluate TAA, we used a model system, which is a lipoprotein suspension of chicken egg yolk that allows evaluating the ability of blood serum to inhibit the accumulation of TBARs in suspension. LPO was induced by adding $\mathrm{FeSO}_{4} \times 7 \mathrm{H}_{2} \mathrm{O}$.

Concentrations of $\alpha$-tocopherol and retinol were determined using the method of R.Ch. Chernyauskene. ${ }^{(22)}$ The method provides for the removal of substances that prevent determination by saponification of samples in the presence of large amounts of ascorbic acid and extraction of unsaponifiable lipids with hexane, followed by fluorometric determination of the content of $\alpha$-tocopherol and retinol. At this, $\alpha$-tocopherol has intense fluorescence with maximum excitation at $\lambda=294 \mathrm{~nm}$ and radiation at $\lambda=330 \mathrm{~nm}$; retinol - at $\lambda=335 \mathrm{~nm}$ and $\lambda=460 \mathrm{~nm}$. The content of GSH and GSSG was determined by P.Y. Hissin and R. Hilf, ${ }^{(23)}$ the SOD activity was determined by H.P. Misra and I. Fridovich. ${ }^{(24)}$ The measurements were conducted with a Shimadzu RF-1501 spectrophotometer (Japan) consisting of two blocks: a UV1650PC spectrophotometer and a RF-1501 spectrofluorimeter.

Statistical analysis was performed using the Statistica 6.1 software package (Stat-Soft Inc., USA). The normality of distribution of continuous variables was tested by the Kolmogorov-Smirnov test with the Lilliefors correction and Shapiro-Wilk test. For descriptive analysis, results are presented as median $(\mathrm{Me})$ and interquartile range (IQR; 25th to 75th percentiles). Differences between groups were tested by the Mann-Whitney U-test. A probability value of $P<0.05$ was considered statistically significant.

\section{Results and Discussion}

Analysis of anthropometric data in both clinical groups showed a statistically significant increase in BW $(P<0.001)$ and BMI $(P<0.001)$ compared to the control groups. At the same time, there were no statistically significant differences between clinical groups (Table 1). Thus, the studied clinical groups were comparable in their main anthropometric indices. 
Table 1.

Anthropometric data of teenage boys of different ethnic groups (Me, IQR $\left.\left./ P_{25} ; P_{75}\right]\right)$

\begin{tabular}{|l|c|c|c|c|}
\hline \multirow{2}{*}{ Parameters } & \multicolumn{2}{|c|}{ Mongoloids } & \multicolumn{2}{c|}{ Caucasians } \\
\cline { 2 - 5 } & $\begin{array}{c}\text { Control } \\
\text { group 1 } \\
(\mathrm{n}=37)\end{array}$ & $\begin{array}{c}\text { Clinical } \\
\text { group 1 } \\
(\mathrm{n}=18)\end{array}$ & $\begin{array}{c}\text { Control } \\
\text { group 2 } \\
(\mathrm{n}=23)\end{array}$ & $\begin{array}{c}\text { Clinical } \\
\text { group 2 } \\
(\mathrm{n}=17)\end{array}$ \\
\hline BW, kg & $\begin{array}{c}45.5 \\
(44.0 ; 50.0)\end{array}$ & $\begin{array}{c}71.0 \\
(63.6 ; 72.5) *\end{array}$ & $\begin{array}{c}63.5 \\
(50 ; 68)\end{array}$ & $\begin{array}{c}88.4 \\
(74.3 ; 113.1)^{*}\end{array}$ \\
\hline Height, cm & $\begin{array}{c}154 \\
(150.3 ; 157.5)\end{array}$ & $\begin{array}{c}155 \\
(150 ; 163)\end{array}$ & $\begin{array}{c}170 \\
(160 ; 176)\end{array}$ & $\begin{array}{c}169 \\
(163 ; 184)\end{array}$ \\
\hline BMI, kg/m² & $\begin{array}{c}19.4 \\
(18.5 ; 20.5)\end{array}$ & $\begin{array}{c}28.0 \\
(28.0 ; 28.7) *\end{array}$ & $\begin{array}{c}21.9 \\
(19.4 ; 22)\end{array}$ & $\begin{array}{c}30.8 \\
(29.5 ; 37.3) *\end{array}$ \\
\hline
\end{tabular}

$*_{-} P<0.05$ - compared to the control group.

Evaluation of the activity of LPO reactions in Clinical group 1 indicated an increase in the content of compounds with DB $(P=0.0013)$ relative to Control group 1 (Table 2$)$. A similar trend was found in the concentration of $\mathrm{CD}(P=0.0017)$ and KD-CT $(P<0.0001)$. An increase in the values of KD-CT turned out to be significant-more than 4 times. In Clinical group 2, we found a statistically significant increase only in the values of KD-CT $(P=0.0025)$ (Table 2$)$. The level of TBARS was not statistically changed in both clinical groups compared to control groups $(P>0.05)$. Interethnic differences were related only to control groups and resulted in lower values of compounds with DB $(P<0.0001)$ and $\mathrm{CD}(P<0.0001)$, and increased levels of TBARS in Mongoloid boys, compared to Caucasians (Table 2).

\section{Table 2.}

State of LPO system in teenage boys of different ethnic groups (Me, IQR $\left.\left./ P_{25} ; P_{75}\right]\right)$

\begin{tabular}{|l|c|c|c|c|}
\hline \multirow{2}{*}{ Parameters } & \multicolumn{2}{|c|}{ Mongoloids } & \multicolumn{2}{c|}{ Caucasians } \\
\cline { 2 - 5 } & $\begin{array}{c}\text { Control } \\
\text { group 1 } \\
(\mathrm{n}=37)\end{array}$ & $\begin{array}{c}\text { Clinical } \\
\text { group 1 } \\
(\mathrm{n}=18)\end{array}$ & $\begin{array}{c}\text { Control } \\
\text { group 2 } \\
(\mathrm{n}=23)\end{array}$ & $\begin{array}{c}\text { Clinical } \\
\text { group 2 } \\
(\mathrm{n}=17)\end{array}$ \\
\hline $\begin{array}{l}\text { Compounds } \\
\text { with conju- } \\
\text { gated DB, } \\
\text { units }\end{array}$ & $\begin{array}{c}1.02 \\
(0.84 ; 1.5)\end{array}$ & $\begin{array}{c}1.83 \\
(1.49 ; 2.07) *\end{array}$ & $\begin{array}{c}2.58 \\
(1.38 ; 3.7)^{\wedge}\end{array}$ & $\begin{array}{c}2.03 \\
(1.86 ; 2.34)\end{array}$ \\
\hline CD, $\mu \mathrm{mol} / \mathrm{L}$ & $\begin{array}{c}0.78 \\
(0.52 ; 0.96)\end{array}$ & $\begin{array}{c}1.22 \\
(1.04 ; 1.42) *\end{array}$ & $\begin{array}{c}2.42 \\
(1.96 ; 2.94)^{\wedge}\end{array}$ & $\begin{array}{c}1.6 \\
(1.52 ; 1.82)\end{array}$ \\
\hline KD-CT, units & $\begin{array}{c}0.14 \\
(0.1 ; 0.2)\end{array}$ & $\begin{array}{c}0.67 \\
(0.42 ; 0.85) *\end{array}$ & $\begin{array}{c}0.26 \\
(0.14 ; 0.38)\end{array}$ & $\begin{array}{c}0.48 \\
(0.32 ; 0.72)^{*}\end{array}$ \\
\hline $\begin{array}{l}\text { TBARS, } \\
\mu \mathrm{mol} / \mathrm{L}\end{array}$ & $\begin{array}{c}1.15 \\
(1.08 ; 0.8)\end{array}$ & $\begin{array}{c}0.95 \\
(0.77 ; 1.22)\end{array}$ & $\begin{array}{c}0.71 \\
(0.61 ; 0.96)^{\wedge}\end{array}$ & $\begin{array}{c}1.26 \\
(0.87 ; 1.41)\end{array}$ \\
\hline
\end{tabular}

$*_{-} P<0.05$ - compared to the control group

$\wedge$ - $P<0.05$ - between two control groups

In the parameters of the AOD system, multidirectional changes of patients parameters compared with the control group were observed in Clinical group 1: the increased values of TAA ( $P=0.0024)$, SOD activity $(P=0.0004)$, and reduced levels of $\alpha$-tocopherol $(P<0.0001)$, retinol $(P<0.0001)$, and GSSG $(P=0.0083$ ) (Table 3$)$. In Clinical group 2 , lower values of $\alpha$-tocopherol $(P=0.0012)$, GSSG $(P=0.018)$, and SOD activity $(P=0.0099)$ were observed relative to Control group 2 . Differences between the two ethnic groups were present in the control groups - the reduced level of TAA $(P<0.0001)$, GSH $(P=0.0017)$ and the increased level of GSSG $(P=0.0009)$ in the group of Mongoloids; just as in clinical groups with NAFLD, a high level of SOD activity $(P=0.0011)$ was observed in Mongoloids compared to Caucasians (Table 3).

Table 3.

State of AOD system in teenage boys of different ethnic groups (Me, $\left.\operatorname{IQR}\left(P_{25} ; P_{75}\right]\right)$

\begin{tabular}{|l|c|c|c|c|}
\hline \multirow{2}{*}{ Parameters } & \multicolumn{2}{|c|}{ Mongoloids } & \multicolumn{2}{c|}{ Caucasians } \\
\cline { 2 - 5 } & $\begin{array}{c}\text { Control } \\
\text { group 1 } \\
(\mathrm{n}=38)\end{array}$ & $\begin{array}{c}\text { Clinical } \\
\text { group 1 } \\
(\mathrm{n}=18)\end{array}$ & $\begin{array}{c}\text { Control } \\
\text { group 2 } \\
(\mathrm{n}=23)\end{array}$ & $\begin{array}{c}\text { Clinical } \\
\text { group 2 } \\
(\mathrm{n}=17)\end{array}$ \\
\hline $\begin{array}{l}\text { TAA, } \\
\text { units }\end{array}$ & $\begin{array}{c}7.27 \\
(6.14 ; 9.24)\end{array}$ & $\begin{array}{c}13.51 \\
(6.02 ; 16.42) *\end{array}$ & $\begin{array}{c}15.48 \\
(13.62 ; 19.01)^{\wedge}\end{array}$ & $\begin{array}{c}16.88 \\
(15.4 ; 19.17)\end{array}$ \\
\hline $\begin{array}{l}\alpha \text {-tocopherol, } \\
\mu \mathrm{mol} / \mathrm{L}\end{array}$ & $\begin{array}{c}6.48 \\
(5.04 ; 7.96)\end{array}$ & $\begin{array}{c}3.6 \\
(2.78 ; 4.69) *\end{array}$ & $\begin{array}{c}7.08 \\
(5.95 ; 9.95)\end{array}$ & $\begin{array}{c}3.66 \\
(3.45 ; 4.72)^{*}\end{array}$ \\
\hline $\begin{array}{l}\text { retinol, } \\
\mu \mathrm{mol} / \mathrm{L}\end{array}$ & $\begin{array}{c}0.61 \\
(0.56 ; 0.68)\end{array}$ & $\begin{array}{c}0.43 \\
(0.34 ; 0.46)^{*}\end{array}$ & $\begin{array}{c}0.59 \\
(0.54 ; 0.75)\end{array}$ & $\begin{array}{c}0.41 \\
(0.33 ; 0.52)\end{array}$ \\
\hline $\begin{array}{l}\mathrm{SOD} \text { activity, } \\
\text { units }\end{array}$ & $\begin{array}{c}1.66 \\
(1.6 ; 1.72)\end{array}$ & $\begin{array}{c}1.85 \\
(1.83 ; 1.87)^{*}\end{array}$ & $\begin{array}{c}1.74 \\
(1.64 ; 1.89)\end{array}$ & $\begin{array}{c}1.45 \\
(1.37 ; 1.8)^{*}\end{array}$ \\
\hline $\begin{array}{l}\text { GSH, } \\
\mathrm{mmol} / \mathrm{L}\end{array}$ & $\begin{array}{c}1.89 \\
(1.8 ; 2.07)\end{array}$ & $\begin{array}{c}1.93 \\
(1.76 ; 2.51)\end{array}$ & $\begin{array}{c}2.22 \\
(2.04 ; 2.46)^{\wedge}\end{array}$ & $\begin{array}{c}2.18 \\
(1.76 ; 2.33)\end{array}$ \\
\hline $\begin{array}{l}\text { GSSG, } \\
\text { mmol/L }\end{array}$ & $\begin{array}{c}2.24 \\
(2.05 ; 2.39)\end{array}$ & $\begin{array}{c}1.94 \\
(1.67 ; 2.22) *\end{array}$ & $\begin{array}{c}2.00 \\
(1.84 ; 2.14)^{\wedge}\end{array}$ & $\begin{array}{c}1.72 \\
(1.41 ; 1.79) *\end{array}$ \\
\hline
\end{tabular}

${ }_{-} P<0.05$ - compared to the control group
$\wedge-P<0.05$ - between two control groups
$\#-P<0.05$ - between two clinical groups

In our study, an intensive accumulation of the secondary LPO products was recorded in both Mongoloid and Caucasian teenagers with obesity and NAFLD. Various studies have shown that ECO is characterized by increased intensity of free radical reactions that contribute to the accumulation of toxic LPO products in the blood. ${ }^{(25,26)}$ Serious metabolic liver disorders in obesity, when excessive accumulation of lipids in hepatocytes occurs, can contribute to the mentioned disorders in the redox state in the presence of NAFLD. ${ }^{(27)}$ Regular intensification of free radical oxidation of hepatic lipids leads to an increase in the content of free fatty acids, a decrease in the rate of their oxidation in mitochondria, an increase in the level of triglycerides, cholesterol in the blood, etc. ${ }^{(3,28)}$ Hypersecretion of proinflammatory cytokines was also observed, including tumor necrosis factor- $\alpha$, interleukin- 6 , and interleukin- $8{ }^{(5)}$ The result of these pathological reactions is hepatocyte necrosis, development of inflammatory cell infiltration, and subsequent activation of fibrogenesis. ${ }^{(3,5,6)}$ Thus, excessive accumulation of toxic LPO products may exacerbate existing damage, preceding the appearance of more serious changes in the metabolism. 
It is known that the parameters of the AOD system are a significant diagnostic criterion of adaptation reactions of the body. ${ }^{(14,15)}$ The increase in TAA values as an integral parameter of the AOD system in Mongoloid teenagers with obesity and NAFLD may indicate activation of compensatory reactions in this group of patients, which is also confirmed by the increased activity of the main antioxidant enzyme-SOD. At the same time, there is a severe deficiency of antioxidant vitamins, $\alpha$-tocopherol and retinol in these patients. In the group of Caucasians with NAFLD, there is also a drastically reduced level of some components of AOD system- $\alpha$ tocopherol, GSSG, and SOD activity. It has been established that $\alpha$-tocopherol and retinol are natural antioxidants and necessary nutritional factors. ${ }^{(15,22,29)}$ Thus, $\alpha$-tocopherol has a high membrane protective and antimutagenic activity, whereby interacting with natural antioxidants of other classes, it acts as an essential regulator of oxidative homeostasis of cells and tissues. ${ }^{(29)}$ The antioxidant function of retinol is expressed in the protection of biomembranes from damage by active forms of oxygen. ${ }^{(30)}$ It is known that the liver is the main pool of fat- and water-soluble vitamins; therefore, we confirmed in our study the decrease in the content of these vitamins in liver damage and their corresponding deficiency at the system level in the teenagers of both ethnic groups. However, interethnic data analysis showed an increased activity of the main antioxidant enzyme SOD in Mongoloid teenagers compared to Caucasians, which may indicate the activation of compensatory processes in the Mongoloid group.

\section{Conclusion}

The changes revealed in the redox state in Mongoloid and Caucasian teenagers with ECO and NAFLD indicate high activity of LPO processes and severe deficiency of antioxidant vitamins in patients of both ethnic groups. Interethnic differences in observed groups were characterized by increased activity of SOD in Mongoloids in comparison with Caucasians. The obtained results allow us to recommend administration of antioxidant drugs in addition to courses of metabolic therapy in comprehensive treatment of patients with NAFLD.

\section{Conflict of interest}

The authors declare that they have no competing interests.

\section{References}

1. Korotkaja NN, Bekezin VV, Borsukov AV, Peresetskaja OV, Druzhinina TV, Pleskachevskaja TA. [Efficacy of phosphogliv in adolescents with fatty hepatosis]. Vestnik Smolenskoy Gosudarstvennoy Medicinskoy Akademii. 2017;16(2):107-113. [Article in Russian].

2. Kirk S, Armstrong S, King E, Trapp C, Grow M, Tucker J, et al. Establishment of the Pediatric Obesity Weight Evaluation

*Corresponding author: Marina A. Darenskaya, PhD, ScD. Scientific Centre for Family Health and Human Reproduction Problems, Irkutsk, the Russian Federation. E-mail: marina_darenskaya@inbox.ru
Registry: A National Research Collaborative for Identifying the Optimal Assessment and Treatment of Pediatric Obesity. Child Obes. 2017;13(1):9-17. doi: 10.1089/chi.2016.0060.

3. Marion AW, Baker AJ, Dhawan A. Fatty liver disease in children. Arch Dis Child. 2004;89(7):648-652.

4. Heymsfield SB, Wadden TA. Mechanisms, Pathophysiology, and Management of Obesity. N Engl J Med. 2017;376(3):254266. doi: 10.1056/NEJMra1514009.

5. Angulo P. Obesity and nonalcoholic fatty liver disease. Nutr Rev. 2007;65(6 Pt 2):S57-63.

6. Sheth SG, Chopra S. Epidemiology, clinical features, and diagnosis of nonalcoholic fatty liver disease in adults. Waltham (MA): UpToDate; 2017.

7. Mehta K, Van Thiel DH, Shah N, Mobarhan S. Nonalcoholic fatty liver disease: pathogenesis and the role of antioxidants. Nutr Rev. 2002;60(9):289-293.

8. Lirussi F1, Azzalini L, Orando S, Orlando R, Angelico F. Antioxidant supplements for non-alcoholic fatty liver disease and/or steatohepatitis. Cochrane Database Syst Rev. 2007;24(1):CD004996.

9. Camacho S, Ruppel A. Is the calorie concept a real solution to the obesity epidemic? Glob Health Action. 2017;10(1):1289650. doi: 10.1080/16549716.2017.1289650.

10. Tutelyan VA, Baturin AK, Kon IYa. [The prevalence of obesity and overweight among the Russian children's population: a multicentre study]. Pediatria. Journal n.a. G.N. Speransky. 2014;93(5):28-31. [Article in Russian].

11. Kolosov YuA, Kolesnikov SI, Anischenko AP, Burdukova $\mathrm{EV}$, Gurevich KG. [Overweight and obesity in children, adolescents and adults: causes of development and risk factors]. Patogenez [Pathogenesis]. 2016;14(4):9-14. [Article in Russian].

12. Pollack H.A. The Problem of Obesity. J Health Polit Policy Law. 2016;41(3):451-2. doi: 10.1215/03616878-3523996.

13. Darenskaya MA, Rychkova LV, Kolesnikov SI., et al. Oxidative stress parameters in adolescent boys with exogenous-constitutional obesity. Free Radical Biology \& Medicine. 2017;112:129-30.

14. Kolesnikova LI, Semyonova NV, Grebenkina LA, Darenskaya MA, Suturina LV, Gnusina S. Integral indicator of oxidative stress in human blood. Bull Exp Biol Med. 2014;157(6):715-7. doi: 10.1007/s10517-014-2649-z.

15. Kolesnikova LI, Darenskaia MA, Grebenkina LA, Suturina LV, Labygina AV, Semenova NV, et al. [Characteristics of the antioxidant system of healthy people of main ethnic groups living near Baikal Lake]. Vopr Pitan. 2012;81(3):46-51. [Article in Russian].

16. Kolesnikova LI, Darenskaya MA, Grebenkina LA, Dolgikh MI, Astakhova TA, Semenova NV. [Gender differences in parameters of lipid metabolism and of level of antioxidants in groups of juveniles--the Evenks and the europeans]. Zh Evol Biokhim Fiziol. 2014 Jan-Feb;50(1):31-7.[Article in Russian]. 17. Kolesnikova LI, Darenskaya MA, Grebenkina LA, Labygina AV, Suturina LV, Dolgikh MI, et al. Activity of lipid peroxidation in infertile women from different populations. Bull Exp Biol Med. 2012;154(2):203-5.

18. Kolesnikova LI, Kolesnikov SI, Darenskaya MA, Grebenkina LA, Semenova NV, Osipova EV, et al. Lipid Status and Predisposing Genes in Patients with Diabetes Mellitus Type 1 from Various Ethnic Groups. Bull Exp Biol Med. 2015;160(2):278-80. doi: 10.1007/s10517-015-3149-5.

19. Volchegorskiı̆ IA, Nalimov AG, Iarovinskiĭ BG, Lifshits RI. [Comparison of various approaches to the determination 
of the products of lipid peroxidation in heptane-isopropanol extracts of blood]. Vopr Med Khim. 1989;35(1):127-31.[Article in Russian].

20. Gavrilov VB, Gavrilova AR, Mazhul' LM. [Methods of determining lipid peroxidation products in the serum using a thiobarbituric acid test].Vopr Med Khim. 1987 JanFeb;33(1):118-22.[Article in Russian].

21. Klebanov GI, Babenkova IV, Teselkin IuO, Komarov OS, Vladimirov IuA. [Evaluation of the antioxidative activity of blood plasma using yolk lipoproteins]. Lab Delo. 1988;(5):5962.[Article in Russian].

22. Cherniauskene RCh, Varshkiavichene ZZ, Gribauskas PS. [Simultaneous fluorometric determination of the concentrations of vitamins E and A in blood serum]. Lab Delo. 1984;(6):362-5. [Article in Russian].

23. Hisin PJ, Hilf R. A fluorometric method for determination of oxidized and reduced glutathione in tissues. Anal Biochem. 1976;74(1):214-26.

24. Misra HP, Fridovich I. The role of superoxide anion in the autoxidation of epinephrine and a simple assay for superoxide dismutase. J Biol Chem. 1972;247(10):3170-5.

25. Furukawa S, Fujita T, Shimabukuro M, Iwaki M,
Yamada Y, Nakajima Y, et al. Increased oxidative stress in obesity and its impact on metabolic syndrome. J Clin Invest. 2004;114(12):1752-61.

26. Darenskaya MA, Gavrilova OA, Rychkova LV, Kravtsova OV, Grebenkina LA, Osipova EV, et al. The assessment of oxidative stress intensity in adolescents with obesity by the integral index. International Journal of Biomedicine.2018;8(1)37-41.

27. McCullough AJ.Pathophysiology of nonalcoholic steatohepatitis. J Clin Gastroenterol. 2006;40 Suppl 1:S17-29. 28. Kolesnikova LI, Darenskaya MA, Grebenkina LA, Dolgikh MI, Semenova NV. [Adaptive reactions of lipid metabolism in native and alien female representatives of Tofalaria population living under extreme environmental conditions]. Zh Evol Biokhim Fiziol. 2014;50(5):343-8. [Article in Russian].

29. Kodentsova VM, Vrzhesinskaia OA, Mazo VK. [Vitamins and oxidative stress]. Vopr Pitan. 2013;82(3):11-8. [Article in Russian].

30. Dadali VA, Tutel'ian VA, Dadali IuV, Kravchenko LV. [Carotenoids. Biological activities]. Vopr Pitan. 2011;80(4):418. [Article in Russian]. 